Materiales de Construcción

Vol. 68, Issue 332, October-December 2018, e169

ISSN-L: 0465-2746

https://doi.org/10.3989/mc.2018.08617

\title{
Influence of bagasse ash with different fineness on alkali-silica reactivity of mortar
}

\author{
S. Ramjan, W. Tangchirapat $\bowtie$, C. Jaturapitakkul \\ Department of Civil Engineering, Faculty of Engineering, King Mongkut's \\ University of Technology Thonburi (KMUTT), (Bangkok, Thailand) \\ \weerachart.tan@kmutt.ac.th
}

\author{
Received 31 August 2017 \\ Accepted 28 February 2018 \\ On line first 9 September 2018
}

\begin{abstract}
This research aimed to study the effect of finenesses of bagasse ash (BGA) on the alkali-silica reaction of mortar. The BGA sample was ground to have particles retained on a sieve No. 325 of $33 \pm 1 \%$ and $5 \pm 1 \%$ by weight. Ground BGA samples were used separately to replace ordinary Portland cement (OPC) at rates of 10, 20, 30 and $40 \%$ by weight of binder to cast mortars. The compressive strengths and the alkali-silica reaction (ASR) of mortars were investigated. The results showed that a large particle size of BGA is not suitable for use in lowering ASR because it results in a low compressive strength and high expansion due to ASR. The mortars containing BGA with higher fineness exhibited higher compressive strength and lower expansion due to ASR than the mortars containing BGA with lower fineness. The results also suggested that the ground BGA retained on a sieve No. 325 of less than $5 \%$ by weight is suitable to be used as a good pozzolan which provides high compressive strength and reduces the expansion of mortar due to ASR even though it contains high LOI. The obtained results also encourage the utilization of ground BGA effectively which leads to reduce the disposal of bagasse ash.
\end{abstract}

KEYWORDS: Alkali-silica reaction; Bagasse ash; Compressive strength; Fineness; Mortar.

Citation/Citar como: Ramjan, S.; Tangchirapat, W.; Jaturapitakkul, C. (2018) Influence of bagasse ash with different fineness on alkali-silica reactivity of mortar. Mater. Construcc. 68 [332], e169 https://doi.org/10.3989/mc.2018.08617

RESUMEN: Influencia de la ceniza de bagazo de diferentes finuras en la reacción álcali-sílice del mortero. Esta investigación tiene como objetivo estudiar el efecto de la finura de la ceniza de bagazo (BGA) en la reacción álcali-sílice del mortero. La muestra de BGA fue molida para conseguir partículas retenidas en un tamiz No. 325 de $33 \pm 1 \%$ y $5 \pm 1 \%$ en peso. Las muestras de BGA molidas fueron utilizadas separadamente para reemplazar el cemento Portland en proporciones del 10, 20, 30 y 40\% en peso en el mortero. Se estudiaron tanto las resistencias a compresión como la reacción álcali-sílice (RAS) de los morteros. Los resultados indicaron que la utilización de un tamaño mayor de las partículas de BGA no es recomendable para disminuir la RAS ya que conlleva a una disminución de las resistencias a compresión y a una alta expansión debido a la RAS. Los morteros que contenían BGA de una mayor finura exhibían mayor resistencia a compresión y una menor expansión, debido a la RAS, que los morteros que contenían BGA de menor finura. Al mismo tiempo los resultados sugieren que el BGA molido retenido en un tamiz No. 325 de menos de un 5\% en peso es apropiado para ser usado como material puzolánico, ya que provee una gran resistencia y reduce la expansión del mortero producido por la RAS a pesar de contener una alta pérdida por calcinación. Los resultados obtenidos también recomiendan la utilización eficiente del BGA molido ya que conlleva una disminución de los desechos de las cenizas de bagazo.

PALABRAS CLAVE: Reacción álcali-sílice; Ceniza de bagazo; Resistencias a compresión; Finura; Mortero.

ORCID ID: S. Ramjan (http://orcid.org/0000-0003-3078-6641); W. Tangchirapat (http://orcid.org/0000-0002-49171367); C. Jaturapitakkul (http://orcid.org/0000-0002-8785-947X)

Copyright: (C) 2018 CSIC. This is an open-access article distributed under the terms of the Creative Commons Attribution 4.0 International (CC BY 4.0) License 


\section{INTRODUCTION}

Bagasse ash (BGA) is a waste product from a sugar industry that is obtained from burning bagasse as a fuel to produce electricity in a power plant. In Thailand, approximately 100 million tons per year of sugarcane are produced (1), and after the production of sugar, the remaining bagasse is approximately $26 \%$ by weight of the sugarcane, i.e., approximately 26 million tons of bagasse. This bagasse has been used as fuel in power plants to generate electricity, and approximately $0.62 \%$ by weight of the sugarcane is bagasse ash (2), or approximately 620,000 tons each year. It is anticipated that the production of sugarcane in Thailand will increase for production of ethanol as an alternative automotive fuel, and for other applications. Previous studies on BGA as a supplementary cementitious material (SCM) have already shown to increase 28 days compressive strength of concrete, reduced dissipation of hydration heat (3), reduced water permeability, and consequently reduced susceptibility for damage from sulfate (4) or chloride infiltration (5). Moreover, bagasse ash can be applied to use as a mixture of quarry dust-lime brick (6). Although many studies confirmed that BGA has good pozzolanic properties, the use of BGA in commercial concrete is not found. In addition, only few research studies of BGA related to alkali-silica reaction are found.

The alkali-silica reaction (ASR) is definitely an infamous damage mechanism as opposed to merely a phenomenon; it is well-known that the ASR is reaction between reactive silica in aggregate and alkali in cement, whereas alkalis are rather considered present in the pore-water (released from cement and/or aggregate materials). In addition, the sub-factors to increase ASR damage of concrete are humidity, temperature, and external alkali in environmental.

Many aggregates are investigated for evaluate the risk on ASR such as recycled aggregate (7) and various coarse aggregates to be used in concrete $(8$, 9 ). However, the use of pozzolan cements or supplementary cementitious materials are found to reduce the ASR in concrete. Chen et al. (10) found that the effective replacement of fly ash class F, slag, and condensed silica fume of 40,65 and $15 \%$ by weight of binder, respectively could reduce the ASR damage. Hanks and Young (11) found that the replacement of cement by fly ash class $F$ at 15, 22.5 and $30 \%$ could reduce ASR expansion; however, the replacement of OPC by fly ash class $\mathrm{F}$ at $7.5 \%$ was not effective to reduce ASR because the expansion of the specimen was more than $0.2 \%$ at 14 days. Kakodkar et al. (12) used different class C fly ashes to investigate the ASR and found that the expansion value due to ASR was below the limit at $0.10 \%$ at 14 days. Awal and Hussin (13) found that the replacement cement by 10,30 and $50 \%$ of palm oil fuel ash by weight of binder could decrease the expansion due to ASR. Zerbino et al. (14) reported that the natural rice husk ash had negative effect than ground rice husk ash on reducing expansion due to ASR and a high amount of ground rice husk ash in mortar was effective to reduce ASR expansion to be lower than $0.1 \%$.

Many researchers (4-6) have confirmed that BGA is a good pozzolan and many pozzolanic materials can be used to inhibit ASR damage. However, using BGA to reduce ASR expansion has been little reported; thus this paper aims to investigate the effect of finenesses and replacements of BGA on ASR.

\section{MATERIALS}

\subsection{Portland cement}

Ordinary Portland cement (OPC) was used in this study. OPC had equivalent $\mathrm{Na}_{2} \mathrm{O}$ of $0.6 \%$; thus it could be classified as a low alkali cement according to ASTM C150 (15). The physical properties of OPC are shown in Table 1 and the chemical compositions are given in Table 2.

\subsection{Bagasse ash}

Bagasse ash (BGA) was obtained from a sugar industry in central part of Thailand. The received bagasse ash directly from the industry or original

TABLE 1. Physical properties of ordinary Portland cement and bagasse ash

\begin{tabular}{lccc}
\hline Properties & Cement & 33BGA & 5BGA \\
\hline Specific gravity & 3.15 & 2.14 & 2.31 \\
Retained on a sieve No. 325 $(\%)$ & N/A & 33.5 & 4.8 \\
Median particle size, $\mathrm{d}_{50}(\mu \mathrm{m})$ & N/A & 20.05 & 16.11 \\
\hline
\end{tabular}

TABLE 2. Chemical compositions of ordinary Portland cement, ground bagasse ash (5BGA sample), and high reactive aggregate

\begin{tabular}{|c|c|c|c|}
\hline Chemical Composition ( $\%)$ & Cement & 5BGA & $\begin{array}{c}\text { High } \\
\text { Reactive } \\
\text { Aggregate }\end{array}$ \\
\hline Silicon Dioxide $\left(\mathrm{SiO}_{2}\right)$ & 20.9 & 52.3 & 5.5 \\
\hline Aluminum Oxide $\left(\mathrm{Al}_{2} \mathrm{O}_{3}\right)$ & 4.8 & 8.6 & 0.5 \\
\hline Ferric Oxide $\left(\mathrm{Fe}_{2} \mathrm{O}_{3}\right)$ & 3.4 & 5.6 & 0.5 \\
\hline Calcium Oxide $(\mathrm{CaO})$ & 65.4 & 13.5 & 91.3 \\
\hline Sulfur Trioxide $\left(\mathrm{SO}_{3}\right)$ & 2.7 & 0.3 & 0.1 \\
\hline Magnesium Oxide (MgO) & 1.3 & 1.5 & 1.7 \\
\hline Sodium Oxide $\left(\mathrm{Na}_{2} \mathrm{O}\right)$ & 0.3 & 0.1 & - \\
\hline Potassium Oxide $\left(\mathrm{K}_{2} \mathrm{O}\right)$ & 0.4 & 2.1 & 0.1 \\
\hline $\mathrm{Na}_{2} \mathrm{O}_{\mathrm{eq}}=\mathrm{Na}_{2} \mathrm{O}+0.658 \mathrm{~K}_{2} \mathrm{O}$ & 0.6 & 1.5 & - \\
\hline Loss On Ignition (LOI) & 1.0 & 16.2 & - \\
\hline
\end{tabular}


BGA had large particles with high moisture content of $50 \%$. The high moisture content of BGA was due to the spraying of water on the bagasse ash to reduce the spreading of dust. Thus, the BGA was placed in an oven at a temperature of $110^{\circ} \mathrm{C}$ for a period of $24 \mathrm{~h}$ and then was screened using a No. 16 sieve to remove large particles and incomplete burning of sugarcane bagasse. Next, the BGA was ground by a ball mill until the particles retained on a No. 325 (opening $45 \mu \mathrm{m}$ ) sieve were $33 \pm 1 \%$ and $5 \pm 1 \%$ by weight in accordance with ASTM C430 (16). The specific gravity of OPC and BGA were determined according to ASTM C188 (17). The abbreviations of BGA with the particles retained on a No. 325 sieve of $33 \pm 1 \%$ and $5 \pm 1 \%$ by weight were defined as 33BGA and 5BGA, respectively. The physical properties of ground BGA are also presented in Table 1.

The different BGA particles were used to investigate the effect of finenesses on ASR. The BGA with particles retained on a No. 325 sieve of $32-34 \%$ was the lowest fineness of a pozzolanic material for use in concrete as specified by ASTM C618 (18) while BGA with particles retained on a No. 325 sieve of $4-6 \%$ were used as a high fineness pozzolan. BGA particles with different finenesses were used to replace OPC at rates of 10, 20, 30, and 40\% by weight of binder for studying the effect of BGA replacement on ASR. Moreover, the fineness of BGA was also presented as the particle size distribution (see Figure 1). The median particle size $\left(\mathrm{d}_{50}\right)$ was the particle with $50 \%$ of cumulative passing from graph of particle size distribution and can be found in Figure 1 which 5BGA and 33BGA had median particle size of 20.05 and $16.11 \mu \mathrm{m}$, respectively.

Figure 2 shows the X-ray diffraction (XRD) analysis of the high fineness of ground BGA (5BGA), plotted using the Lin (count) and 2q. The mineral compositions of BGA were identified by X-ray

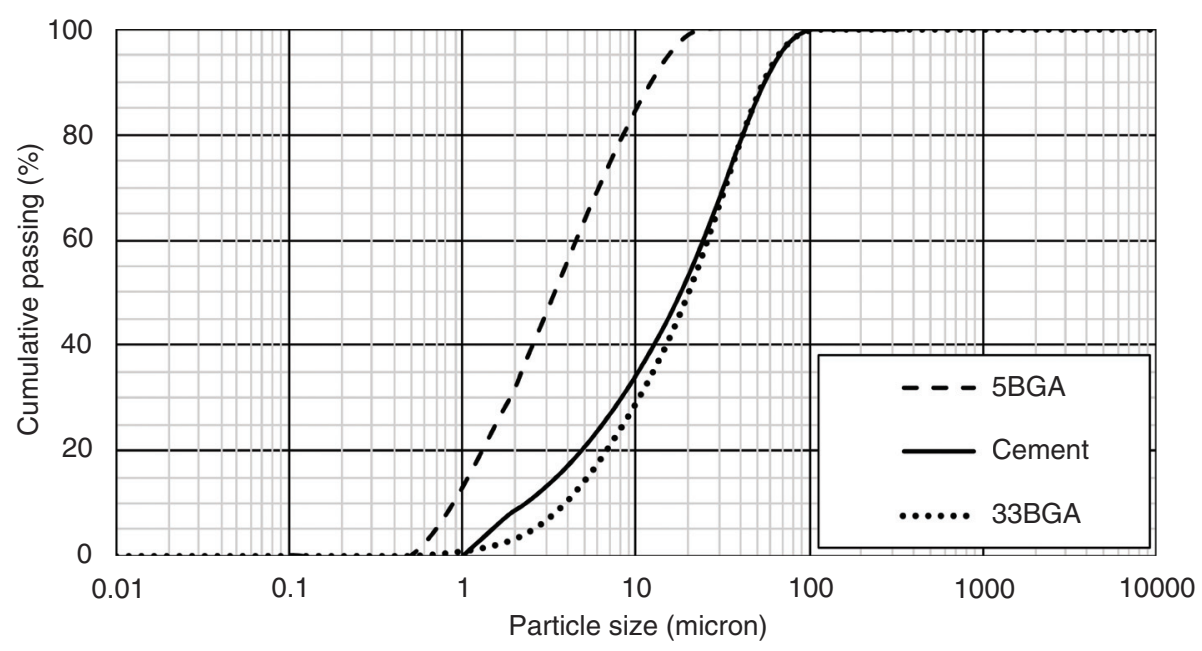

FIGURE 1. Particle size distribution of materials

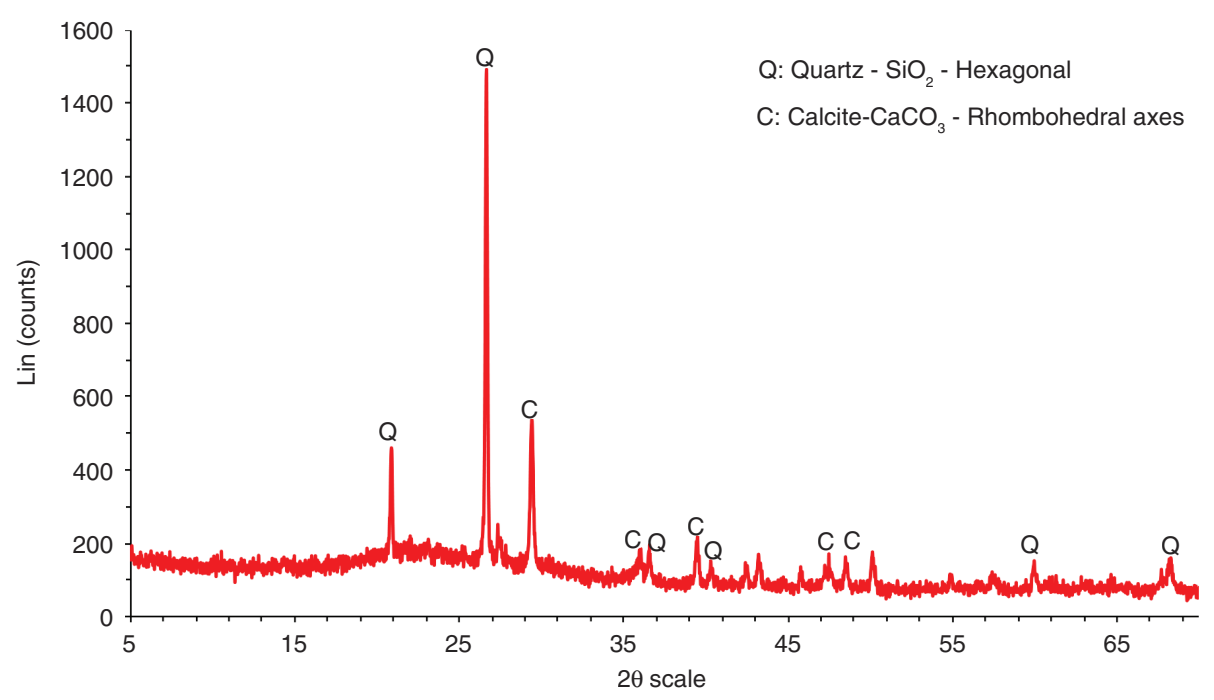

FIGURE 2. X-ray diffraction (XRD) of ground BGA (5BGA sample) 
diffractometer; Bruker AXS model D8 Discover. The conditions of test were targeted $\mathrm{Cu}$, voltage $40 \mathrm{kV}$, current $40 \mathrm{~mA}$ and scanning from 5 to 70 ${ }^{\circ} 2 \mathrm{q}$ with increment 0.02 degree/step and scan speed $0.2 \mathrm{~second} / \mathrm{step}$. The results presented the clear peak of quartz $\mathrm{SiO}_{2}$ of hexagonal type and calcite $\left(\mathrm{CaCO}_{3}\right)$ in the form of Rhombo $\mathrm{H}$ axes. Scanning electron microscope (SEM) of 5BGA and 33BGA samples (from JEOL model JSM-6610) using accelerating voltage $15-20 \mathrm{kV}$, magnification 1000-2000 times, and other details are presented in Figure 3 and Figure 4, respectively. The SEM images of the ground BGA showed that 5BGA had smaller particles and was crushed into irregular shapes while 33BGA had large particles and high porosity.

For the chemical compositions shown in Table 2, 5BGA sample was only used to determine the chemical compositions because the finenesses of pozzolans did not affect the chemical compositions (19). Chemical compositions of the materials were identified by wavelength-dispersive X-ray fluorescence

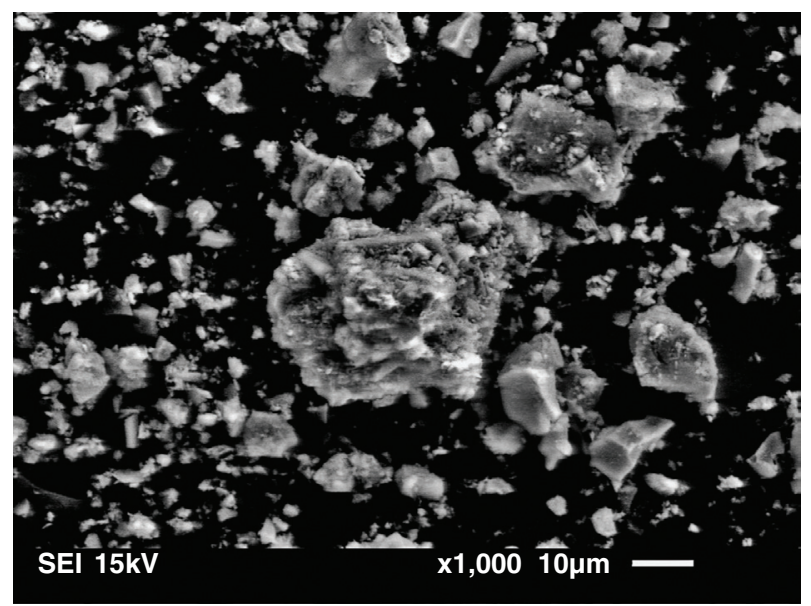

Figure 3. SEM image of ground BGA (5BGA sample)

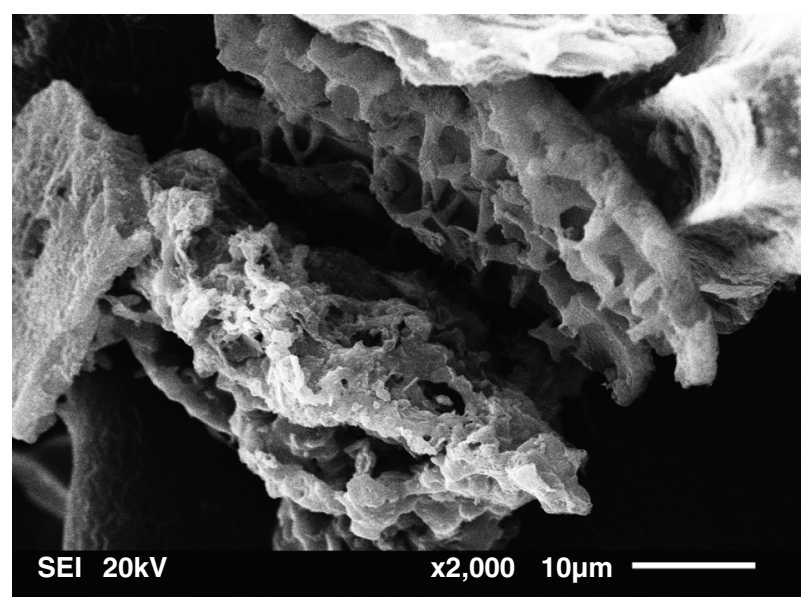

FIgURE 4. SEM image of ground BGA (33BGA sample) spectrometer (WD-XRF) model Bruker S4 Explorer and the conditions test were $50 \mathrm{kV}$ of voltage, current $250 \mu \mathrm{A}$, beam filter $\mathrm{Cu} 250 \mu \mathrm{m}$, live time 100s, and limit $50 \mathrm{KCps}$. In this study, 5BGA had $\mathrm{SiO}_{2}+$ $\mathrm{Al}_{2} \mathrm{O}_{3}+\mathrm{Fe}_{2} \mathrm{O}_{3}$ of $66.5 \%$ and less than $4 \% \mathrm{SO}_{3}$ by weight. The oxides of $\mathrm{Na}_{2} \mathrm{O}$ and $\mathrm{K}_{2} \mathrm{O}$ were $0.1 \%$ and $2.1 \%$, respectively. Thus the $\mathrm{Na}_{2} \mathrm{O}$ equivalent content was calculated to be $1.5 \%$, which was lower than the limited values recommended by Glauz et al. (20), who found that alkali content lower than 3\% of fly ash class $\mathrm{F}$ or pozzolan class $\mathrm{N}$ was effective against ASR. The major oxide of $\mathrm{BGA}$ was $\mathrm{SiO}_{2}$, representing $52.3 \%$, suggesting that a high content of $\mathrm{SiO}_{2}$ and a low alkali content of BGA was a suitable for use as a pozzolanic material.

The loss on ignition of the ground bagasse ash was $16.2 \%$, which was higher than $6 \%$ and did not meet the requirement of ASTM C618 (18) for class F fly ash. The high LOI of BGA was due to the incomplete combustion process which did not remove totally the organic phase included the calcite in BGA also contributed to LOI. In addition, LOI of BGA was investigated at the temperature of $750 \pm 50^{\circ} \mathrm{C}$ according to ASTM C311 (21), both organic phase and calcite were burnt caused to weight loss.

However, many researchers $(4,22)$ confirmed that the high LOI of bagasse ash at 19.36 to $20.4 \%$ had little effect on the compressive strength and sulfate resistance of concrete or mortar. Moreover, the use of bagasse ash with high LOI to investigate the expansion due to ASR of mortar was rarely found.

\subsection{Aggregates}

For compressive strength test, a river sand was used as a fine aggregate. The fine aggregate had a specific gravity of 2.64 , a water absorption of $1.21 \%$, and a fineness modulus of 1.52.

For ASR test, a crushed coarse aggregate with highly reactive was used to investigate the effect of finenesses and cement replacement of BGA on ASR. This highly reactive aggregate from central of Thailand was used as a fine aggregate and was processed to have a grading requirement according to ASTM C1567 (23), as shown in Table 3. The fine aggregate had a specific gravity of 2.63 with water

TABLE 3. Grading requirement of the fine aggregate used to investigate ASR

\begin{tabular}{lcc}
\hline \multicolumn{2}{c}{ Sieve Size } & \\
\cline { 1 - 2 } Passing & Retaining & Mass (\%) \\
\hline $4.75 \mathrm{~mm}$ (No. 4) & $2.36 \mathrm{~mm}$ (No. 8) & 10 \\
$2.36 \mathrm{~mm}$ (No. 8) & $1.18 \mathrm{~mm}$ (No. 16) & 25 \\
$1.18 \mathrm{~mm}$ (No. 16) & $600 \mu \mathrm{m}$ (No. 30) & 25 \\
$600 \mu \mathrm{m}$ (No. 30) & $300 \mu \mathrm{m}$ (No. 50) & 25 \\
$300 \mu \mathrm{m}$ (No. 50) & $150 \mu \mathrm{m}$ (No. 100) & 15 \\
\hline
\end{tabular}


absorption of $0.83 \%$. The high reactive aggregate was investigated for the mineral properties and found that the high reactive aggregate was siliceous limestone with major mineral composition of calcite included minors of quartz and dolomite (see Figure 5). Chemical compositions of the high reactive aggregate showed $\mathrm{CaO}$ of $91.3 \%, \mathrm{SiO}_{2}$ of $5.5 \%$, and other compositions in small percentages (see Table 2).

\section{SAMPLE PREPARATION \& EXPERIMENTAL METHODS}

\subsection{Sample preparation}

Mortar cubes of $50 \times 50 \times 50 \mathrm{~mm}^{3}$ were cast to investigate the compressive strength of mortar containing ground BGA with different finenesses and replacements. River sand was used as a fine aggregate. The ratio of binder to fine aggregate was set as a constant $1: 2.75$ by weight, and all mortars were prepared to have flow at the range of 105 to $115 \%$, as shown in Table 4. Note that the use of ground BGA to replace OPC required higher water to maintain the flow between $105-115 \%$. For example, the use of 5BGA to replace OPC of $10,20,30$, and $40 \%$ required $\mathrm{W} / \mathrm{B}$ ratios of $0.69,0.71,0.73$, and 0.76 , respectively, while the $\mathrm{W} / \mathrm{B}$ ratio of control mortar (CT mortar) was 0.67. Moreover, use of coarser BGA (33BGA) to replace OPC required a higher water content than the use of finer BGA (5BGA) and the higher replacement of 33BGA resulted in the higher water requirement to maintain the specified flow of mortar. For example, 33BGA20 mortar had a W/B ratio of 0.76 while that of 5BGA20 mortar had W/B ratio of 0.71 . This was due to the irregular shapes and high porosity of the large particles of BGA, which caused more friction and absorb more water than the small particles of BGA. The result was in agreement with the findings of other researches (24), who used ground rice husk ash and limestone filler to replace cement.

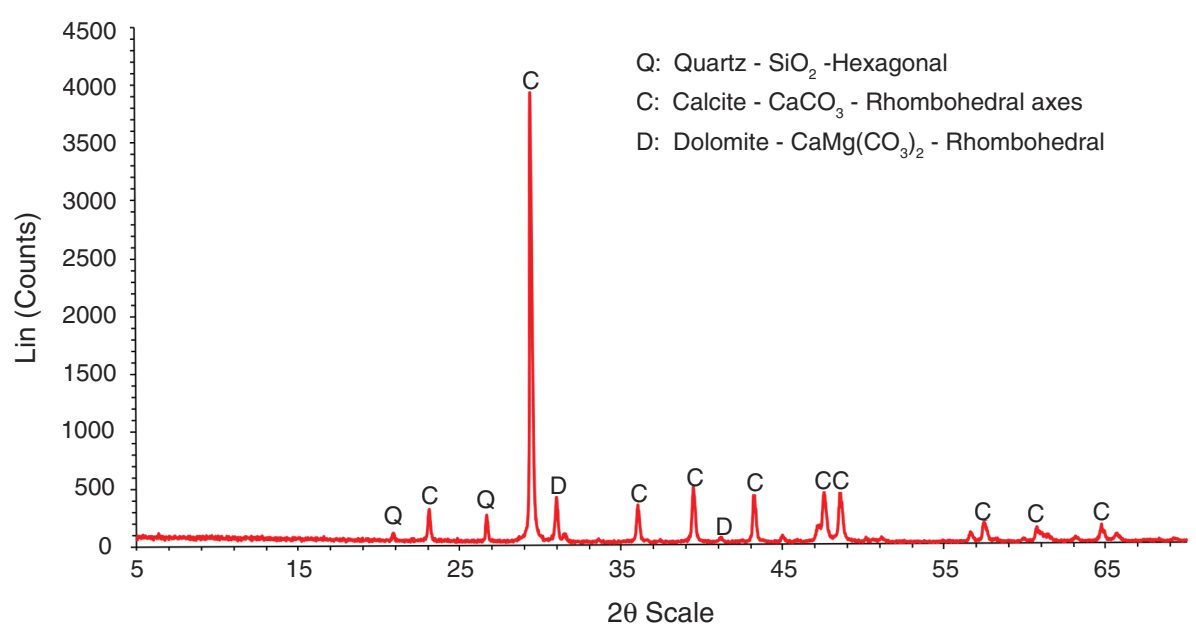

FIGURE 5. X-ray diffraction (XRD) of high reactive aggregate

TABLE 4. Mix proportions of the mortars used to investigate compressive strength when the flow of mortar is in the ranges of 105 to $115 \%$

\begin{tabular}{lccccc}
\hline & \multicolumn{5}{c}{ Mix Proportions ( by Weight) } \\
\cline { 2 - 4 } Mixes & Cement & BGA & Sand & W/B & Percentage of W/B \\
\hline CT & 1.00 & 0.00 & 2.75 & 0.67 & 100 \\
5BGA10 & 0.90 & 0.10 & 2.75 & 0.69 & 103 \\
5BGA20 & 0.80 & 0.20 & 2.75 & 0.71 & 106 \\
5BGA30 & 0.70 & 0.30 & 2.75 & 0.73 & 109 \\
5BGA40 & 0.60 & 0.40 & 2.75 & 0.76 & 114 \\
33BGA10 & 0.90 & 0.10 & 2.75 & 0.72 & 108 \\
33BGA20 & 0.80 & 0.20 & 2.75 & 0.76 & 114 \\
33BGA30 & 0.70 & 0.30 & 2.75 & 0.81 & 121 \\
33BGA40 & 0.60 & 0.40 & 2.75 & 0.87 & 130 \\
\hline
\end{tabular}

Note: $\mathrm{CT}$ is the control mortar

5BGAxx or 33BGAxx is the mortar containing BGA with particles retained on a No. 325 sieve of 5 or $33 \%$ at a replacement rate of $\mathrm{xx}$ 
Mortar prisms with $25 \times 25 \mathrm{~mm}^{2}$ in cross section and $285 \mathrm{~mm}$ in length were cast. In addition, ground BGA samples with different finenesses were also used separately to replace Portland cement at rate of 10, 20, 30 , and $40 \%$ by weight of binder. The binder to fine aggregate (highly reactive aggregate) ratio was set as a constant of $1: 2.25$ by weight to cast mortar. The waterto-binder (W/B) ratio of 0.47 was used for ASR test, as specified by ASTM C1567 (23).

\subsection{Experimental methods}

After casting for $24 \mathrm{~h}$, the mortar cubes of $5 \times 5 \times$ $5 \mathrm{~cm}^{3}$ were removed from the molds and then cured in saturated lime water. The compressive strengths of mortars were determined at the ages of 7, 28, 60 and 90 days. At each testing age, five mortar specimens were tested, and the average value was used as suggested by ASTM C109 (25).

The alkali silica reactivity potential of the aggregate was assessed following the procedure described in ASTM C1567 (23). The accelerated mortar bar test method was used to determine ASR by increasing temperature and using sodium hydroxide $(\mathrm{NaOH})$ solution for increasing the concentration of external alkali for activating the silica in aggregate. The mortar bars were removed from the molds after casting for $24 \mathrm{~h}$, cured in water at temperature of $80^{\circ} \mathrm{C}$ for $24 \mathrm{~h}$, and then immersed in $1 \mathrm{~N}$ sodium hydroxide $(\mathrm{NaOH})$ solution (which had volume $4 \pm 0.5$ times of the sample). Mortar bars were measured the length until 28 days and the length change was calculated using equation (1). According to ASTM C1567 (23), the mortar with expansion below $0.10 \%$ is considered the aggregate as innocuous, that between $0.1-0.2 \%$ is considered the aggregate as slow reactive, and that higher than $0.2 \%$ is considered the aggregate as high reactive [1].

$$
L=\frac{L_{X}-L_{i}}{G} \times 100
$$

where $L=$ change in length at $\mathrm{x}$ age, $\% ; L x=$ comparator reading of the specimen at $\mathrm{x}$ age minus comparator reading of reference bar at $\mathrm{x}$ age, $\mathrm{mm}$; $L \mathrm{i}=$ initial comparator reading of the specimen minus comparator reading of reference bar at that same time, $\mathrm{mm} ; G=$ nominal gage length, $250 \mathrm{~mm}$.

\section{RESULTS AND DISCUSSION}

\subsection{Compressive strength of mortar}

Figure 6 and Figure 7 present the relationship between the compressive strength of mortar and replacement of ordinary Portland cement by 5BGA and 33BGA, respectively. The control mortar (CT) had compressive strengths of 22.8 and $29.4 \mathrm{MPa}$ at the ages of 7 and 28 days, respectively, and increased to 32.2 and $33.5 \mathrm{MPa}$ at the ages of 60 and 90 days, respectively. At 28 days, mortars containing 5BGA at rates of $10,20,30$, and $40 \%$ by weight of binder had compressive strengths of 27.5, 26.6, 24.1, and 23.2 MPa or 94, 90, 82, and 79\% of CT mortar, respectively. 5BGA mortars had compressive strength more than $75 \%$ of CT mortar at 28 days. Moreover, the compressive strengths of 5BGA10, 5BGA20, 5BGA30, and 5BGA40 mortars could increase to 102, 92, 86, and $81 \%$ of CT mortar, respectively at 90 days. For mortars containing 33BGA at rates of 10 to $40 \%$ by weight of binder had compressive strengths of 87 to $52 \%$ of CT mortar at 28 days and increased to 90 to $54 \%$ of CT mortar at 90 days. The results showed that the compressive strengths of mortars containing small particles of BGA (5BGA) were higher than the mortars containing large particles of BGA (33BGA), consistent with many researchers studied the use of concrete or mortar containing bagasse ash (3) or other pozzolans, such as fly ash and palm oil fuel ash $(26,27)$.

The mortars containing smaller particles of ground BGA produced higher compressive strength than the mortars containing larger BGA particles at all ages. This was due to two factors, the first factor was 5BGA had smaller particles and higher surface area; thus, 5BGA had faster reactive and higher area for reaction than 33BGA particles, and the second factor was that the filler effect of smaller particles of 5BGA filled voids in the matrix and made the matrix denser (24). Similar results were found by other researchers $(24,28)$, they used other pozzolans as a replacement of cement.

The replacement of 5BGA at $10 \%$ by weight of binder (5BGA10 mortar) gave the highest compressive strength of 101 and $102 \%$ of CT mortar at 60 and 90 days, respectively. Note that 5BGA10 mortar had W/B ratio higher than CT mortar of 3\%. In general the higher W/B ratio the lower compressive strength; however, $10 \%$ of BGA as a cement replacement could produce compressive strength from pozzolanic reaction higher than the loss of $10 \%$ of hydration reaction by cement. The results also suggested that the high LOI of BGA $(16.2 \%)$ had little effect on the compressive strength of mortar and was similar to the other results $(22,29)$.

In the case of coarse BGA (33BGA), the mortar containing $33 \mathrm{BGA}$ at $10 \%$ replacement of cement gave lower compressive strength than CT mortar but the strength was still higher than $80 \%$ of CT mortar at all ages and the mortar 33BGA20 gave the compressive strength higher than $75 \%$ of CT mortar at 28 days. When 33BGA was used to replace cement at 30 and $40 \%, 33$ BGA 30 and 33BGA40 mortars gave the compressive strengths lower than $75 \%$ of CT mortar or at the ranges of $47-59 \%$ of CT mortar. The replacement of OPC by 33BGA affected the reduction of $\mathrm{CaO}$ from OPC which was the main oxide for producing $\mathrm{Ca}(\mathrm{OH})_{2}$, it was the substrate to produce the pozzolanic reaction. In addition, 33BGA mortar had high water to binder 


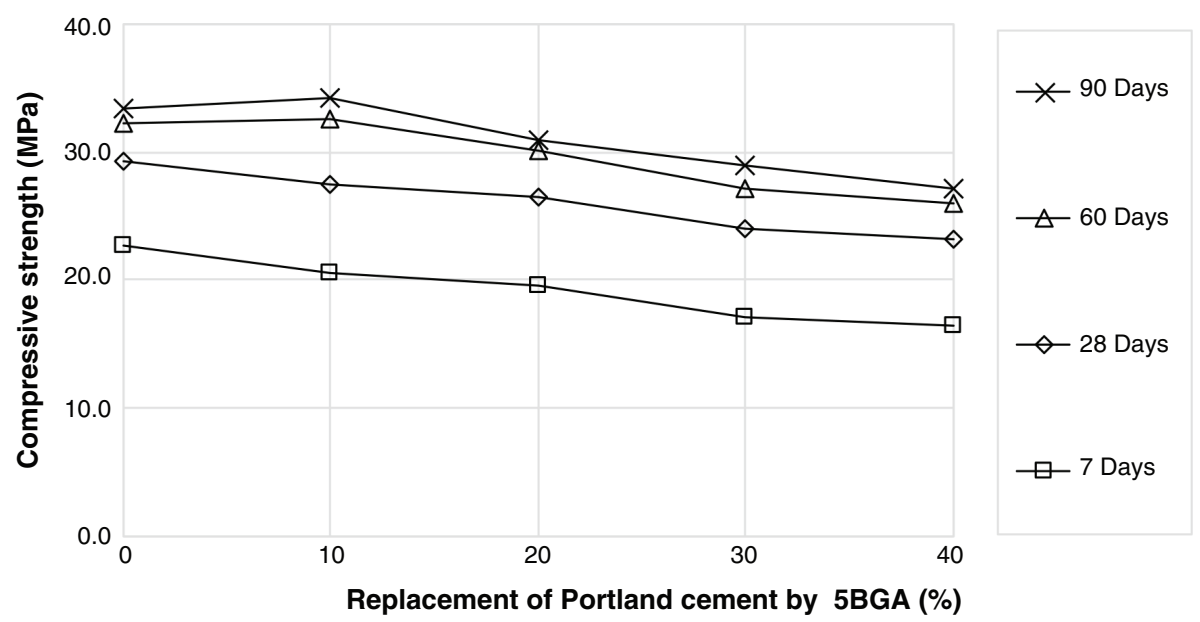

FIGURE 6. Relationship between the compressive strength of mortar and the replacement of Portland cement by 5BGA

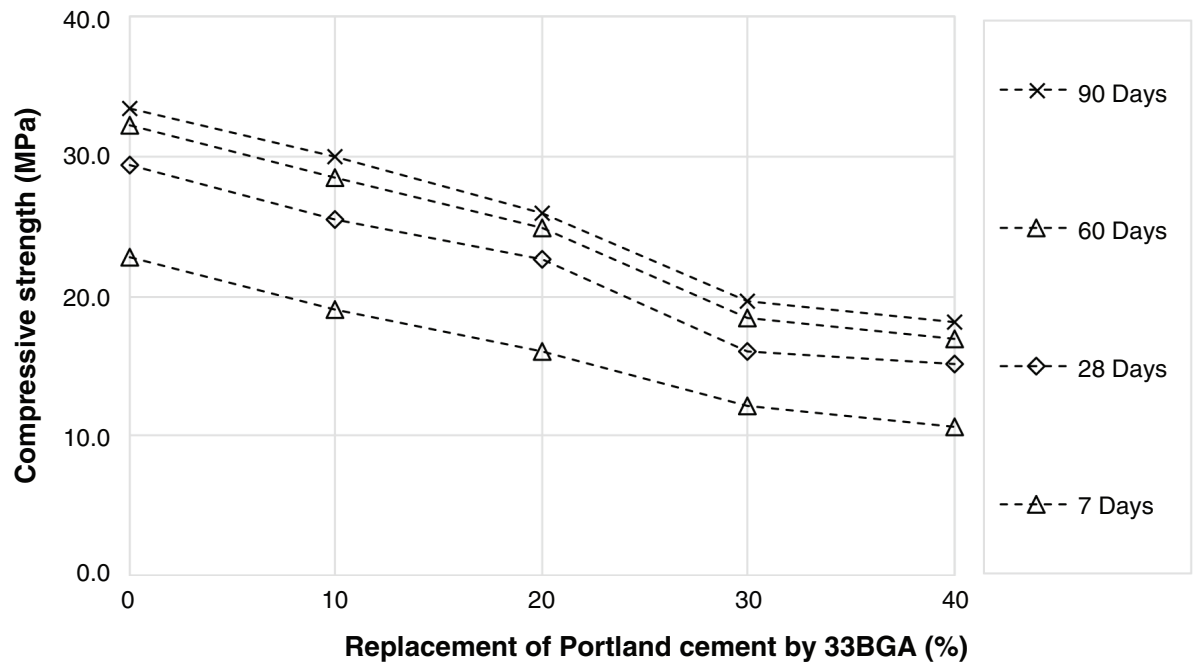

FigURE 7. Relationship between the compressive strength of mortar and the replacement of Portland cement by 33BGA

ratio included 33BGA had large particles caused the low compressive strength of mortar. This result was consistent with many studies, from which the use of smaller particles of pozzolanic materials provided higher compressive strength than the coarser one in concrete (30). However, 5BGA mortars utilized lower water content than 33BGA mortars to control flow at range of $110 \pm 5 \%$ and the low $\mathrm{W} / \mathrm{B}$ ratio was a factor to provide more compressive strength of mortar.

\subsection{Effect of the fineness of bagasse ash on the expansion of mortar due to alkali-silica reaction}

Figure 8 shows the expansion of $\mathrm{CT}$ and 5BGA mortars, which are immersed in $1 \mathrm{~N} \mathrm{NaOH}$ solution at a period of 28 days. CT mortar had an expansion due to ASR more than $0.20 \%$ at 14 days and the expansion increased to $0.38 \%$ at 28 days, suggesting that the aggregate used in the mixture was highly reactive for ASR because the expansion limitation for innocuous aggregate in mortar due to ASR was not more than $0.10 \%$ at 14 days.

When 5BGA was used to replace Portland cement at rates of $10,20,30$, and $40 \%$ by weight of binder, the expansions of mortars due to ASR were reduced. For example, mortars 5BGA10, 5BGA20, 5BGA30, and 5BGA40 had the expansions due to ASR of $0.1269,0.0532,0.0436$, and $0.0435 \%$, respectively, at 14 days and increased to $0.2661,0.1274,0.1019$, and $0.1195 \%$, respectively, at 28 days. The reduction of the expansion due to ASR depended on the replacement of BGA in mortar. Moreover, the effective replacement of 5BGA was $20 \%$ up to $40 \%$ by weight of binder because the mortars with these replacement rates could provide low expansions due to ASR at 14 days in the ranges of $0.043-0.053 \%$, which were lower than $0.10 \%$. The mechanism of reducing the potential ASR by the use of supplementary cementitious 


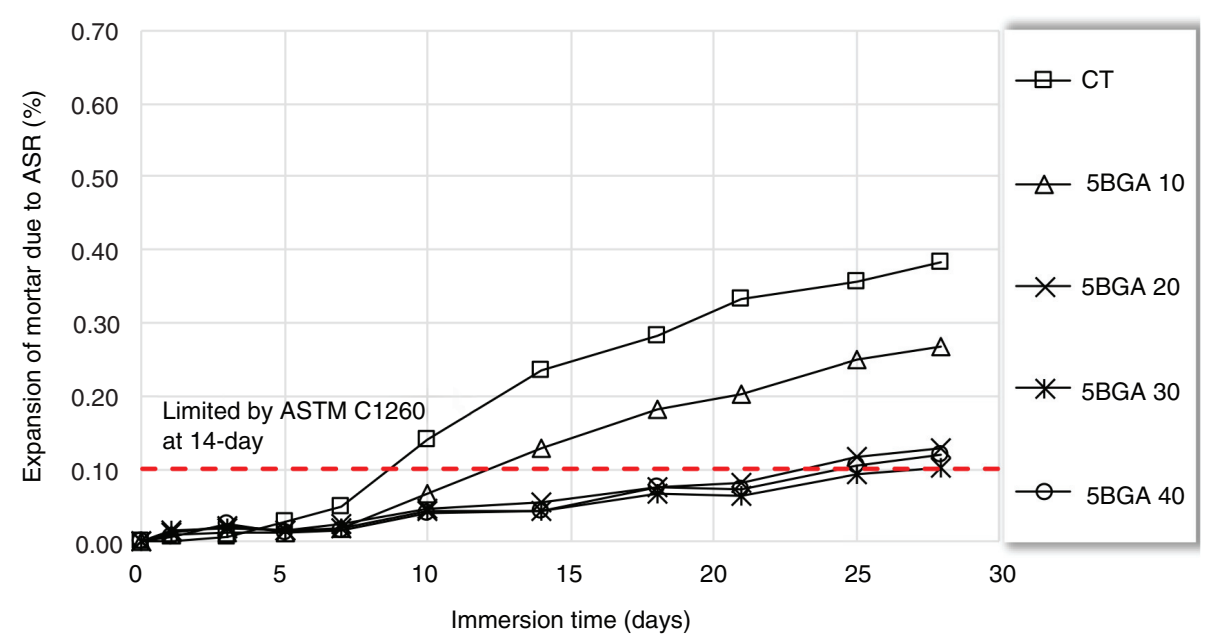

FIGURE 8. Relationship between expansion of 5BGA mortars due to ASR and immersion time

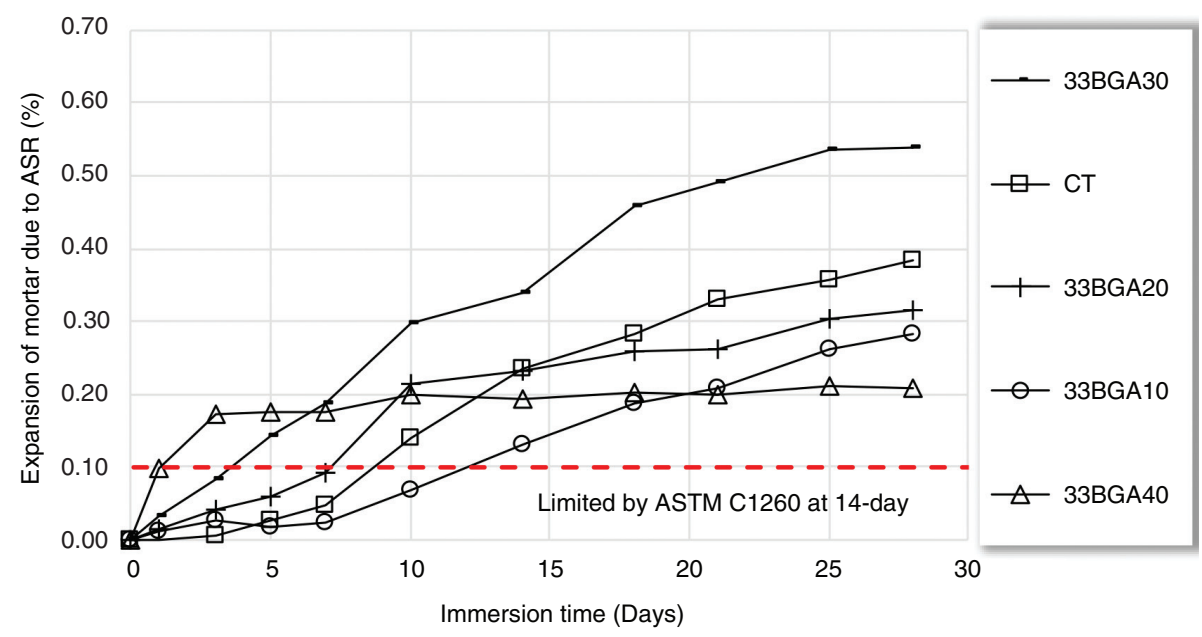

FIGURE 9. Relationship between expansion of 33BGA mortars due to ASR and immersion time

materials (SCMs) or pozzolan cement was reported by many researchers (31-36) since pozzolanic materials could react with $\mathrm{Ca}(\mathrm{OH})_{2}$ and led to decrease concentration of hydroxyl ion and $\mathrm{pH}$ in pore solutions. Moreover, the use of pozzolan with low alkali content replaced OPC caused reduction of the total alkali contribution (37).

Figure 9 presents the results of ASR expansions of mortars containing 33BGA at rates of 10 to $40 \%$ by weight of binder. 33BGA10, 33BGA20, 33BGA30, and 33BGA40 mortars had the expansions due to ASR at 14 days of $0.1299,0.2315$, 0.3376 , and $0.1922 \%$, respectively, and the expansions were $0.2831,0.3144,0.5379$, and $0.2093 \%$, respectively at 28 days. Note that the mortars containing 33BGA had the expansions due to ASR higher than $0.10 \%$.
According to ASTM C618 (18), the expansion due to ASR of mortar at 14 days should be less than that of CT mortar. This finding suggested that the mortars containing 5BGA at all replacement rates and the mortars containing 33BGA at rates of 10 , 20 , and $40 \%$ resulted in the expansion due to ASR being less than that of CT mortar.

Figure 10 presents the surfaces of mortars containing high and low finenesses of BGA. The figures demonstrated that the use of 5BGA was much more effective than 33BGA in reducing the expansion of mortar due to ASR. The replacing 33BGA at 10 and $20 \%$ in mortar provided expansions lower than CT mortar; however, the mortars with 30 to $40 \%$ replacement had higher expansions due to ASR and cracks were observed in the mortar bars, as shown in Figure 10. Mortar 33BGA40 had crumbly surfaces, 
although it exhibited a low expansion and also a low compressive strength. Moreover, 20 and 30\% replacements of 33BGA resulted in many cracks in the mortars.

Replacing OPC by 5BGA caused a reduction of $\mathrm{CaO}$ and alkali in the binder, which was a substrate of ASR; thus this reaction was lower. This finding was similar to Aydin et al. (38) who used original fly ash and ground fly ash to replace cement at rates of $5-60 \%$ and caused a reduction of $\mathrm{CaO}$ in the binder. They found that the ground fly ash was more effective to reduce ASR expansion than original fly ash and the effective replacement of both original and ground fly ashes were 40 to $60 \%$ by weight of binder.

In this study, OPC had high amount of $\mathrm{CaO}$ while BGA was primarily composed of $\mathrm{SiO}_{2}$. When OPC was replaced by BGA, the amount of $\mathrm{CaO}$ was decreased, whereas $\mathrm{SiO}_{2}$ was increased from which the lower $\mathrm{CaO}$ and the higher $\mathrm{SiO}_{2}$ had affected to lower expansion due to ASR

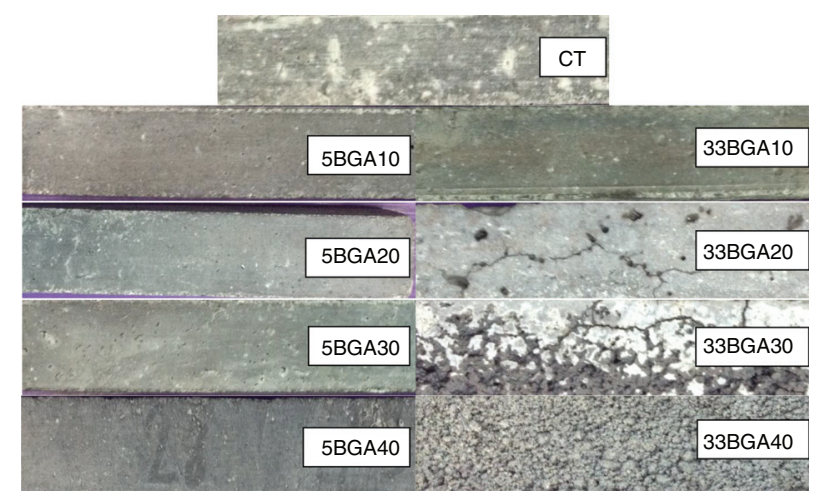

FIGURE 10. The surface of CT mortar and mortar bars containing BGA after a period of 28 days exposure to $1 \mathrm{~N}$ $\mathrm{NaOH}$ at $80^{\circ} \mathrm{C}$ because low $\mathrm{CaO}$ produced low $\mathrm{Ca}(\mathrm{OH})_{2}$ content (which was a part of substrate), while a higher $\mathrm{SiO}_{2}$ in BGA could react with $\mathrm{Ca}(\mathrm{OH})_{2}$ to form to $\mathrm{C}-\mathrm{S}-\mathrm{H}$; thus, a denser paste was obtained. According to the report of Forster, et al. (35), the pozzolan cement had a $\mathrm{CaO} / \mathrm{SiO}_{2}$ ratio lower than OPC from which more C-S-H gel could entrap more alkalis and reduce the $\mathrm{pH}$ in pore fluid in the concrete. Figure 11 presents the pore size distributions of 5BGA pastes which were investigated by using mercury intrusion porosimetry (MIP) method. Pastes for this investigation were removed from the mold after $24 \mathrm{~h}$ for casting and cured in boil water at $80{ }^{\circ} \mathrm{C}$ for period of $24 \mathrm{~h}$ before immersion in $\mathrm{NaOH}$ solution. The results showed that 5BGA10, 5BGA20, 5BGA30, and $C T$ pastes had cumulative pore volume in the same ranges while 5BGA40 paste had high cumulative pore volume. However, pore volume and pore size of paste reduced with the increased paste ages (39).

However, the above explanation could not be used for mortars containing 33BGA because the reduction of $\mathrm{CaO} / \mathrm{SiO}_{2}$ ratio in 33BGA mortars resulted in a higher ASR expansion compared to mortar containing 5BGA. 33BGA had many large particles and less surface area than 5BGA; thus, silica in 33BGA was low reactive and caused more alkali to remain in cement, resulting in higher ASR. Moreover, 33BGA could not fill voids in mortar (due to large particles) and produced low compressive strength; thus, a sodium hydroxide solution could easily penetrate into mortar to activate silica, both in aggregate and 33BGA, causing more alkali-silica reactions. In addition, high fineness of BGA could better react with $\mathrm{Ca}(\mathrm{OH})_{2}$ from hydration reaction and reduced the amount of $\mathrm{CaO}$ and $\mathrm{SiO}_{2}$ for producing ASR lower than the BGA with low fineness. The result was similar

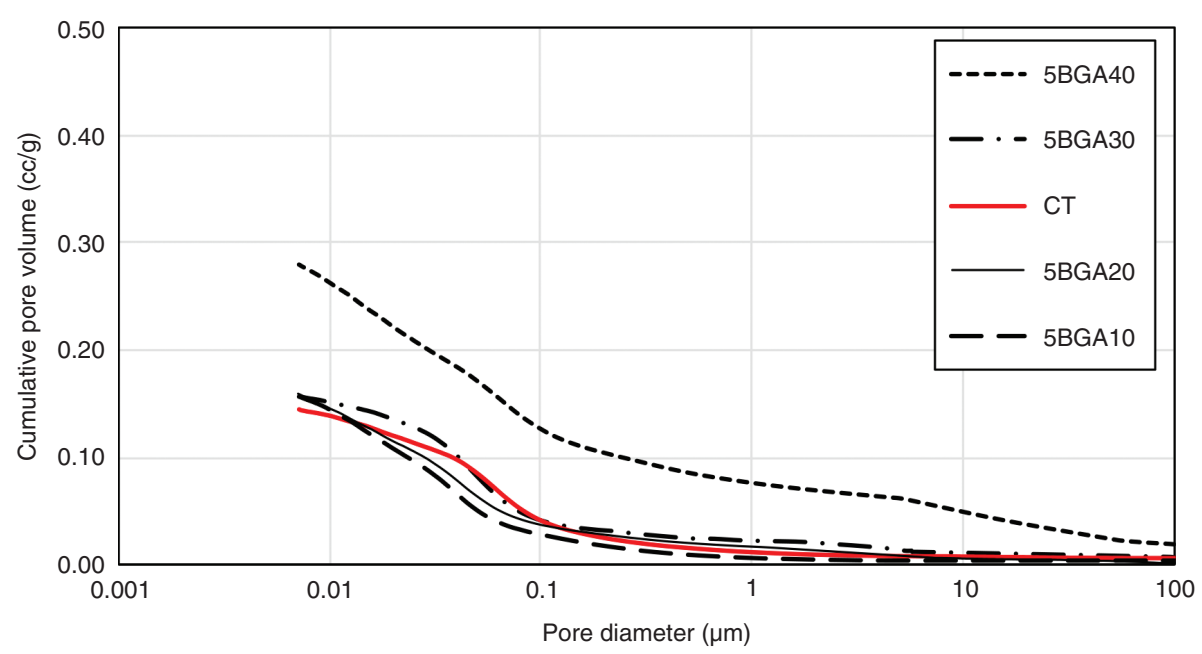

FIGURE 11. Pore size distribution of 5BGA pastes 


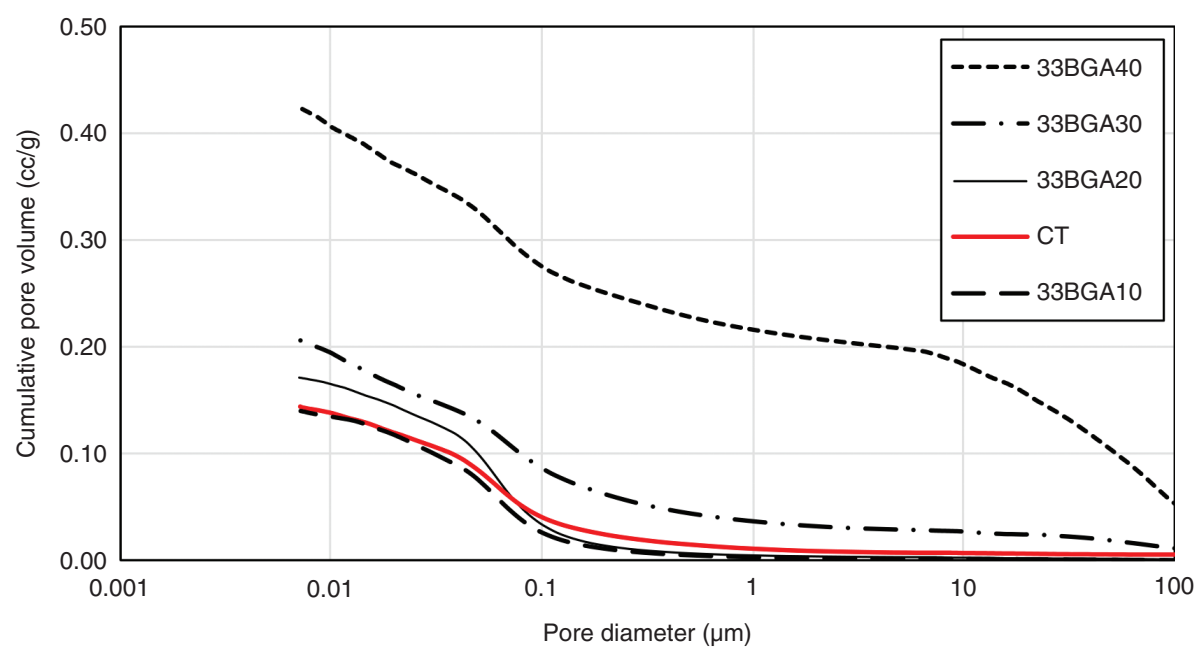

FIGURE 12. Pore size distribution of 33BGA pastes

to the use of rice husk ash with different finenesses studied by Zerbino et al. (14) who reported that the unground rice husk ash affected high expansion due to ASR of mortar while the use of ground rice husk ash could reduce expansion due to ASR of mortar to be lower than $0.10 \%$. The pore size distribution of 33BGA pastes are given in Figure 12, 33BGA40 paste had high cumulative pore volume. The results confirmed that the higher replacement of OPC by 33BGA resulted in higher amount of pores and voids.

In contrast, the replacement of OPC by 5BGA in mortar reduced $\mathrm{Ca}(\mathrm{OH})_{2}$ due to the pozzolanic reaction, thus, produced the lower ASR gel and resulting in a low expansion due to ASR. Moreover, the reduction of $\mathrm{Ca}(\mathrm{OH})_{2}$ and the production of more $\mathrm{C}-\mathrm{S}-\mathrm{H}$ gel due to the pozzolanic reaction resulted in a denser paste and caused the low permeability and slowly ASR to be occurred.

Note that high LOI of BGA did not affect the expansion due to ASR because 5BGA, which had a high LOI of $16.2 \%$, could be used effectively to reduce the expansion due to ASR. Likewise, the other pozzolan such as palm oil fuel ash (POFA) from research of Awal and Hussin (13), which had high LOI of $18 \%$ could prevent the expansion of mortars while the results of the use of high LOI biomass fly ash $(10.4 \%)$ on ASR could reduce the expansion compared with CT mortar similarly to this research (40).

\section{CONCLUSIONS}

The conclusions of this investigation are summarized as follows:

1. Mortars containing higher fineness BGA could produce higher compressive strength than that with lower fineness. Replacing 10\% of bagasse ash (BGA) with particles retained on a No. 325 sieve of $5 \%$ by weight give higher compressive strength of mortar than CT mortar at the age of 60 days or more.

2. High fineness of BGA (5BGA) could be used effectively to increase the resistance of ASR; however, low fineness of BGA (33BGA) was not as effective as the high fineness BGA to reduce the expansion of mortar due to ASR.

3. Replacement of OPC by 5BGA at rates of $20-30 \%$ could be used to reduce the effect of ASR (expansion below $0.10 \%$ ) and also produced the compressive strength of mortar more than $85 \%$ of CT mortar at the age of 90 days.

4. Although the mortars containing $10-20 \%$ of 33BGA in binder gave the compressive strength higher than $77 \%$ of $\mathrm{CT}$ mortar at 28 days, 33BGA was not suitable to be used to control ASR in mortar or concrete.

\section{ACKNOWLEDGMENTS}

The authors gratefully acknowledge the financial supports from the Thailand Research Fund (TRF) and King Mongkut's University of Technology Thonburi (KMUTT) under the Institutional Research Capability Development Grant.

\section{REFERENCES}

1. Office of Cane and Sugar Board (2014) Report on total cane crushing and sugar production 2013/2014. Thailand: Ministry of Industry.

2. Cordeiro, G.; Filjp, R.; Fairbairn, E.; Luis, M.; Oliver, C. (2004) Influence of mechanical grinding on the pozzolanic activity of residual sugarcane bagasse ash. Proceedings of an international conference on use of recycled materials in building and structures, 1-9. 
3. Montakarntiwong, K.; Chusilp, N.; Tangchirapat, W.; Jaturapitakkul, C. (2013) Strength and heat evolution of concretes containing bagasse ash from thermal power plants in sugar industry. Mater. Des. 49 [0], 414-420. https://doi.org/10.1016/j.matdes.2013.01.031

4. Chusilp, N.; Jaturapitakkul, C.; Kiattikomol, K. (2009) Effects of LOI of ground bagasse ash on the compressive strength and sulfate resistance of mortars. Constr. Build. Mater. 23 [12], 3523-3531. https://doi.org/10.1016/j. conbuildmat.2009.06.046

5. Amin, N.U. (2011) Use of bagasse ash in concrete and its impact on the strength and chloride resistivity. J. Mater. Civil. Eng. 23 [5], 717-720. https://doi.org/10.1061/(ASCE) MT.1943-5533.0000227

6. Madurwar, M.V.; Mandavgane, S.A.; Ralegaonkar, R.V. (2014) Development and feasibility analysis of bagasse ash bricks. J. Energ. Eng. 141 [3] 04014022. http://dx.doi. org/10.1061/(ASCE)EY.1943-7897.0000200

7. Etxeberria, M.; Vázquez, E. (2010) Alkali silica reaction in concrete induced by mortar adhered to recycled aggregate. Mater. Construcc. 60 [297], 47-58. http://dx.doi. org/10.3989/mc.2010.46508

8. Olague, C.; Castro, P.; Lopez, W. (2002) Alkali-silica reaction of aggregates for concrete pavements in Chihuahua's State, Mexico. Mater. Construcc. 52 [268], 19-31. http:// dx.doi.org/10.3989/mc.2002.v52.i268.314

9. Latifee, E.R.; Rangaraju, P.R. (2015) Miniature Concrete Prism Test: Rapid Test Method for Evaluating Alkali-Silica Reactivity of Aggregates. J. Mater. Civil. Eng. 27 [7] 04014215. https://doi.org/10.1061/(ASCE) MT.1943-5533.0001183

10. Chen, H.; Soles, J.A.; Malhotra, V.M. (1993) Investigations of supplementary cementing materials for reducing alkaliaggregate reactions. Cem. Concr. Compos. 15 [1], 75-84. https://doi.org/10.1016/0958-9465(93)90039-C

11. Hanks, D.L.; Young, D.T. (1997) Accelerated testing and mitigation of the alkali-silica reaction using low-calcium fly ash. The 4th CANMETIACI International Conference on Durability of Concrete. Supplementary Papers, Sydney, Australia, 205-220.

12. Kakodkar, S.; Ramakrishnan, V.; Zimmerman, L. (1997) Addition of class $\mathrm{C}$ fly ash to control expansions due to alkali-silica reaction. Trans. Res. Rec. 1458. 109-117. https://trid.trb.org/view.aspx?id=424773

13. Awal, A. A.; Hussin, M. W. (1997) The effectiveness of palm oil fuel ash in preventing expansion due to alkali-silica reaction. Cem. Concr. Compos. 19 [4], 367-372. https:// doi.org/10.1016/S0958-9465(97)00034-6

14. Zerbino, R.; Giaccio, G.; Batic, O.; Isaia, G. (2012) Alkalisilica reaction in mortars and concretes incorporating natural rice husk ash. Constr. Build. Mater. 36, 796-806. https://doi.org/10.1016/j.conbuildmat.2012.04.049

15. ASTM C150/150M (2012) Standard specification for Portland cement. ASTM International. West Conshohocken. PA.

16. ASTM C430 (2008) Standard Test Method for Fineness of Hydraulic Cement by the $45-\mu \mathrm{m}$ (No. 325) Sieve. ASTM International. West Conshohocken. PA.

17. ASTM C188 (2017) Standard Test Method for Density of Hydraulic Cement. ASTM International. West Conshohocken. PA

18. ASTM C618 (2012) Standard Specification for Coal Fly Ash and Raw or Calcined Natural Pozzolan for Use in Concrete. ASTM International. West Conshohocken. PA.

19. Paya, J.; Monzo, J.; Borrachero, M.V.; Peris, E. (1995) Mechanical treatments of fly ashes. Part I: physico-chemical characterization of ground fly ashes. Cem. Concr. Rese. 25 [7], 1469-1479. https://doi.org/10.1016/0008-8846(95) $00141-X$

20. Glauz, D.L.; Roberts, D.; Jain, V.; Moussavi, H.; Llewellen, R.; Lenz, V. (1996) Evaluate the use of mineral admixtures in concrete to mitigate alkali-silica reaction. Report No. FHWA/CA/OR-97-01, Office of Materials Engineering and Testing Service, California Department of Transport, 85. https://trid.trb.org/view.aspx?id $=483816$
21. ASTM C311/C311M (2013) Sampling and testing fly ash or natural pozzolans for use in Portland-cement concrete. ASTM International. West Conshohocken. PA

22. Somna, R.; Jaturapitakkul, C.; Rattanachu, P.; Chalee, W. (2012) Effect of ground bagasse ash on mechanical and durability properties of recycled aggregate concrete. Mater. Des. 36 [0], 597-603. https://doi.org/10.1016/j. matdes.2011.11.065

23. ASTM C1567 (2013) Standard test method for determining the potential alkali-silica reactivity of combinations of cementitious materials and aggregate (accelerated mortar-bar method) ASTM International. West Conshohocken. PA

24. Isaia, G. C.; Gastaldini, A. L. G.; Moraes, R. (2003) Physical and pozzolanic action of mineral additions on the mechanical strength of high performance concrete. Cem. Concr. Res. 25 [1], 69-76. https://doi.org/10.1016/ S0958-9465(01)00057-9

25. ASTM C109/C109M (2013) Standard test method for compressive strength of hydraulic cement mortars (Using 2-in. or [50-mm] Cube Specimens). ASTM International. West Conshohocken. PA.

26. Chindaprasirt, P.; Jaturapitakkul, C.; Sinsiri, T. (2005) Effect of fly ash fineness on compressive strength and pore size of blended cement paste. Cem. Concr. Compos. 27 [4], 425-428. https://doi.org/10.1016/j.cemconcomp. 2004.07.003

27. Kroehong, W.; Sinsiri, T.; Jaturapitakkul, C. (2011) Effect of palm oil fuel ash fineness on packing effect and pozzolanic reaction of blended cement paste. Procedia Engineering. 14, 361-369. https://doi.org/10.1016/j.proeng.2011.07.045

28. Kiattikomol, K.; Jaturapitakkul, C.; Songpiriyakij, S.; Chutubtim, A. (2001) study of ground coarse fly ashes with different finenesses from various sources as pozzolanic materials. Cem. Concr. Compos. 23 [4-5], 335-343. https://doi.org/10.1016/S0958-9465(01)00016-6

29. Chusilp, N.; Jaturapitakkul, C.; Kiattikomol, K. (2009) Utilization of bagasse ash as a pozzolanic material in concrete. Constr. Build. Mater. 23 [11], 3352-3358. https://doi. $\mathrm{org} / 10.1016 / \mathrm{j}$. conbuildmat.2009.06.030

30. Paya, J.; Monzo, J.; Borrachero, M.V.; Peris, E.; Amahjour, F. (2000) Mechanical treatments of fly ashes. Part IV: strength development of ground fly ash-cement mortars cured at different temperatures. Cem. Concr. Rese. 30 [4], 543-551. https://doi.org/10.1016/S0008-8846(00)00218-0

31. Dunstan, E.R. (1981) The effect of fly ash on concrete alkali-aggregate reaction. Cement. Concrete. Aggr. 3 [2], 101-104. http://dx.doi.org/10.1520/CCA10212J

32. Nixon, P.; Page, C.; (1987) Pore solution chemistry and alkali aggregate reaction. Amer. Conc. I. SP-100 [2], 1833-1862.

33. Chatterji, S.; Thaulow, N.; Jensen, A. (1989) Studies of alkali-silica reaction. Part 5. Verification of a newly proposed reaction mechanism. Cem. Concr. Rese. 19 [2], 177-183. https://doi.org/10.1016/0008-8846(89)90081-1

34. Helmuth, R.; Stark, D.; Diamond, S.; MoranvilleRegourd, M. (1993) Alkali-silica reactivity: an overview of research. SHRP-C-342, Strategic Highway Research Program, National Research Council, Washington, D.C., 202

35. Forster, S. W.; Akers, D. J.; Lee, M. K.; Pergalsky, A.; Arrand, C. D.; Lewis, D. W.; Pierce, J. S.; Barger, G. S.; MacDonald, D. R.; Pisaneschi, R. R. (1998) Report on alkali-aggregate reactivity. Amer. Conc. I. ACI. 221. 1 R-98, 31.

36. Kandasamy, S.; Shehata, M.H. (2014) The capacity of ternary blends containing slag and high-calcium fly ash to mitigate alkali silica reaction. Cem. Concr. Compos. 49, 92-99. https://doi.org/10.1016/j. cemconcomp.2013.12.008

37. Lane, D.S.; Ozyildirim, H.C. (1995) Use of fly ash, slag, or silica fume to inhibit alkali-silica reactivity. Final report. Virginia Transportation Research Council, Charlottesville, VA (United States) https://www.osti.gov/ scitech/biblio/104263

38. Aydın, S.; Karatay, C.; Baradan, B. (2010) The effect of grinding process on mechanical properties and alkali-silica reaction resistance of fly ash incorporated cement mortar. 
12 S. Ramjan et al.

Powder. Technol. 197 [1-2], 68-72. https://doi.org/10.1016/j. powtec.2009.08.020

39. Ma, Y.; Hu, J.; Ye, G. (2013) The pore structure and permeability of alkali activated fly ash. Fuel. 104 [Supplement C], 771-780. https://doi.org/10.1016/j.fuel.2012.05.034
40. Esteves, T.C.; Rajamma, R.; Soares, D.; Silva, A.S.; Ferreira, V.M.; Labrincha, J.A. (2012) Use of biomass fly ash for mitigation of alkali-silica reaction of cement mortars. Constr. Build. Mater. 26, 687-693. https://doi. org/10.1016/j.conbuildmat.2011.06.075 